\title{
Synthesis, Structural Analysis and Thermal Behavior of New 1,2,4-Triazole Derivative and Its Transition Metal Complexes
}

\author{
Ali Talib Bader ${ }^{*}$, Nada Ahmed Rasheed Al-qasii ${ }^{2}$, Ahmed Hassen Shntaif ${ }^{1}$, Maryam El Marouani ${ }^{3}$, \\ Mohammed Idaan Hassan AL Majidi ${ }^{1,4}$, László Trif ${ }^{5}$, and Mohammed Boulhaoua ${ }^{4}$ \\ ${ }^{1}$ Department of Chemistry, College of Sciences for Woman, University of Babylon, Hilla, Iraq \\ ${ }^{2}$ Department of Chemistry, College of Science, University of Baghdad, Baghdad, Iraq \\ ${ }^{3}$ Department of Chemistry, College of Sciences, University of Hafr Al Batin, Hafr Al Batin, Kingdom of Saudi Arabia \\ ${ }^{4}$ Institute of Chemistry, ELTE Eötvös Loránd University, Pázmány Péter sétány 1/A, H-1117, Budapest, Hungary \\ ${ }^{5}$ Institute of Materials and Environmental Chemistry, Research Centre for Natural Sciences, Budapest, Hungary
}

\section{${ }^{*}$ Corresponding author:}

tel: $+964-7710783571$

email:wsc.ali.taleb@uobabylon.edu.iq

Received: September 3, 2021

Accepted: November 3, 2021

DOI: $10.22146 /$ ijc. 68859

\begin{abstract}
Cobalt(II), nickel(II), and copper(II) complexes containing bidentate ligands (5-(4-nitrophenyl)-4-((4-phenoxybenzylidene)amino)-4H-1,2,4-triazole-3-thiol) could be synthesized by the condensation reaction between 1,2,4-triazole derivative and $\mathrm{p}$ phenoxy benzaldehyde. The ligand and its complexes were characterized by various spectroscopic techniques such as FTIR, UV-visible, ${ }^{1} \mathrm{H}$ and ${ }^{13} \mathrm{C}-\mathrm{NMR}$, element analysis, molar conductance, and magnetic susceptibility test. The new ligand was exploited as a ligand to coordinate with $\mathrm{Co}(\mathrm{II}), \mathrm{Ni}(\mathrm{II})$, and $\mathrm{Cu}(\mathrm{II})$ by a molar ratio of 1:2 (metal:ligand). The prepared complexes $\left(C_{1}, C_{2}\right.$, and $\left.C_{3}\right)$ were exposed to thermo-gravimetric analysis (TGA/DTG) under an inert atmosphere to investigate their thermal stability. The ligand (L) degradation was also investigated as a reference. The results indicated that the complexes proposed structures had an octahedral geometry.
\end{abstract}

Keywords: 1,2,4-triazole; Schiff base; thermal analysis; metal complexes

\section{- INTRODUCTION}

Heterocyclic compounds are organic molecules that contain a minimum of two different atom types in the ring [1]. Heterocyclic compounds with different donor atoms, like $\mathrm{S}, \mathrm{N}$, or $\mathrm{O}$, tend to form metal chelates or coordination compounds utilized as active antibacterial agents [2]. 1,2,4-triazole is one of the most important aromatic heterocyclic nitrogen-rich molecules [3-4]. There is increasing attention to the triazole substructure's potential application as urease and lipase enzyme inhibitors [5]. Linking the triazole moiety to a reasonably selected and different biologically active agent fragment would form new complexes that might have better biological activity because of the synergistic effects [6-7].

Furthermore, these compounds have multiple sites for metal atoms to coordinate with, forming more stable transition metal complexes that are bioactive triazole- based. Recently, significant effort has been devoted to studying the thermal degradation characteristics under inert and oxidative atmospheres. In this work, we determined the first synthesis and characterization of a new Schiff base triazole derivative and its cobalt(II), nickel(II), and copper(II) complexes. Common spectroscopic techniques such as ${ }^{1} \mathrm{H}-\mathrm{NMR},{ }^{13} \mathrm{C}-\mathrm{NMR}$, FTIR, UV-Vis, elemental analysis, and thermal analysis were used to characterize the synthesized compounds. We have examined the thermal degradation profile of the prepared complexes to highlight their energy potential and the far-reaching possibilities of their use.

\section{- EXPERIMENTAL SECTION}

\section{Materials}

The 4-nitro benzoic acid, absolute ethanol, hydrazine hydrate $80 \%$, acetic acid, carbon disulfide, 
potassium hydroxide, and 4-phenoxy benzaldehyde were supplied by Sigma-Aldrich (Germany), and the metal salt $\mathrm{CoCl}_{2} \cdot 6 \mathrm{H}_{2} \mathrm{O}, \mathrm{NiCl}_{2} \cdot 6 \mathrm{H}_{2} \mathrm{O}$, and $\mathrm{CuCl}_{2} \cdot 6 \mathrm{H}_{2} \mathrm{O}$ were supplied by Fluka (Germany). All chemicals were used without further purification.

\section{Instrumentation}

The Nuclear magnetic resonance (NMR) measurements of the synthesized compounds were performed at $500 \mathrm{MHz}$ in DMSO-d6 at $25^{\circ} \mathrm{C}$ on Bruker DRX-500 spectrometer using the deuterium signal of the solvent as the lock and tetramethylsilane (TMS) as the internal standard. Varian 2000 (Scimitar Series) FTIR spectrometer with MCT (mercury-cadmium-telluride) detector and single reflection diamond ATR unit (Varian Inc., US) (Specac Ltd, UK) was used to record infrared (IR) spectra. For a single spectrum, 32 individual scans were averaged at a resolution of $4 \mathrm{~cm}^{-1}$, and the instrument's data acquisition software (ResPro 4.0) was used to ATR-correct all the spectra. A PerkinElmer UV/Vis Lambda 35 spectrometer was used to conduct the spectrophotometric measurements by applying acetonitrile as a solvent and a slit width of $1 \mathrm{~nm}$.

\section{Procedure}

\section{Synthesizes of ethyl 4-nitrobenzoate}

Dropwise additions of $\mathrm{H}_{2} \mathrm{SO}_{4}(3 \mathrm{~mL})$ to a mixture of $5 \mathrm{~g}(0.025 \mathrm{~mol})$ of 4 -nitrobenzoic acid in $50 \mathrm{~mL}$ ethanol were heated under reflux for $6 \mathrm{~h}$. The precipitate formed after cooling, and the excess ethanol was evaporated. The solid product was washed with a sodium bicarbonate solution, filtered, rinsed with cold water, dried, and recrystallized from ethanol to yield, as shown in Scheme 1.

\section{Synthesizes of 4-nitrobenzohydrazide}

Hydrazine hydrate $(80 \%, 20 \mathrm{~mL})$ was added to a solution of ethyl 4-nitrobenzoate by dissolving (5 g, $0.027 \mathrm{~mol}$ ) in $50 \mathrm{~mL}$ of absolute ethanol, and then the mixture was heated under reflux for $8 \mathrm{~h}$. Finally, the mixture was allowed to cool, and a solid product was filtered, washed with cold water, dried, and recrystallized from ethanol to produce 4-nitrobenzohydrazide, as shown in Scheme 1.

\section{Synthesized of potassium nitrobenzoyl)hydrazine-1-carbodithioate}

The 4-nitrobenzohydrazide ( $4 \mathrm{~g}, 0.022 \mathrm{~mol}$ ) was treated at $0{ }^{\circ} \mathrm{C}$ with stirring in a solution of $2.5 \mathrm{~g}(0.044$ mol) potassium hydroxide in $40 \mathrm{~mL}$ ethanol. Dropwise additions of $7 \mathrm{~mL}$ ( $0.2 \mathrm{~mol})$ carbon disulfide were made to the reaction mixture, agitated overnight at room temperature. The reaction was then cooled with $200 \mathrm{~mL}$ diethyl ether, which was agitated for $10 \mathrm{~min}$. The solid result was then filtered, washed with cold ethanol, and dried to yield potassium 2-(4-nitrobenzoyl)hydrazine-1carbodithioate, as shown in Scheme 1.

\section{Synthesis of 4-amino-5-(4-nitrophenyl)-4H-1,2,4- triazole-3-thiol}

The synthesis used a reported procedure in the literatures [8-9]. Potassium 2-(4-nitrobenzoyl)hydrazine1-carbodithioate $(3.5 \mathrm{~g}, 0.011 \mathrm{~mol})$ was heated under reflux for $6 \mathrm{~h}$ in excess of hydrazine hydrate (approximately $30 \mathrm{~mL}$ ). The color of the lead acetate sheet changed from black to white to release hydrogen sulfide gas by changing the color of the mixture from black-green to light yellow. The chilled mixture was put into $30 \mathrm{~mL}$ of ice water and acidified with concentrated hydrochloric acid ( $\mathrm{pH} 2-3$ ). To get 4-amino-5-(4nitrophenyl)-4H-1,2,4-triazole-3-thiol, the precipitate was filtered, rinsed with cold water, dried, and recrystallized from ethanol.

\section{Synthesis of Schiff base (ligand L)}

A hot solution of 4-amino-5-(4-nitrophenyl)-4H1,2,4-triazole-3-thiol $(0.237 \mathrm{~g}, 1 \mathrm{mmol})$ in $15 \mathrm{~mL}$ of EtOH was added dropwise to a solution of $p$ phenoxybenzaldehyde $(0.198 \mathrm{~g}, 0.001 \mathrm{~mol})$ in the presence of three drops of glacial acetic acid $(\mathrm{AcOH})$, The reaction mixture was refluxed for $4 \mathrm{~h}$. The resulting yellow compound was filtered and then dried in air to yield the required Schiff base ligand (L) as a yellow solid (yield: 78\%, MP: $270-272{ }^{\circ} \mathrm{C}$ ) (Scheme 1).

\section{Synthesis of metal ions complexes}

The complexes $\left(\mathrm{C}_{1}, \mathrm{C}_{2}, \mathrm{C}_{3}\right)$ were synthesized as shown in Scheme 1 by adding the hot ethanolic solution of the metal ions $\left(\mathrm{CoCl}_{2} \cdot 6 \mathrm{H}_{2} \mathrm{O}, \mathrm{NiCl}_{2} \cdot 6 \mathrm{H}_{2} \mathrm{O}\right.$, and $\left.\mathrm{CuCl}_{2} \cdot 2 \mathrm{H}_{2} \mathrm{O}\right)$ to the hot ligand (L) $(0.834 \mathrm{~g}, 2 \mathrm{mmol})$ 
ethanolic solution in 1:2 (metal: ligand) molar ratio. The reaction mixture was refluxed for $1 \mathrm{~h}$, and colored precipitates were formed. Then, the obtained complexes were filtered and recrystallized from ethanol. Table 1 shows the number of metal salts in the complexes [10].

\section{- RESULTS AND DISCUSSION}

Table 2 shows the results of metal content determination by atomic absorption, chloride content,
CHNS elemental analysis, and the physical features of the ligand and its metal complexes. The suggestion of the molecular formula of the studied compounds was made relying on spectral data, atomic absorption analysis, chloride content, CHNS, and conductivity measurements. Table 2 shows the metal complexes' analytical data. The complexes formation was revealed by these data having a 1:2 (ligand:metal ion) ratio, showing that the Schiff base ligand was a chelating agent.

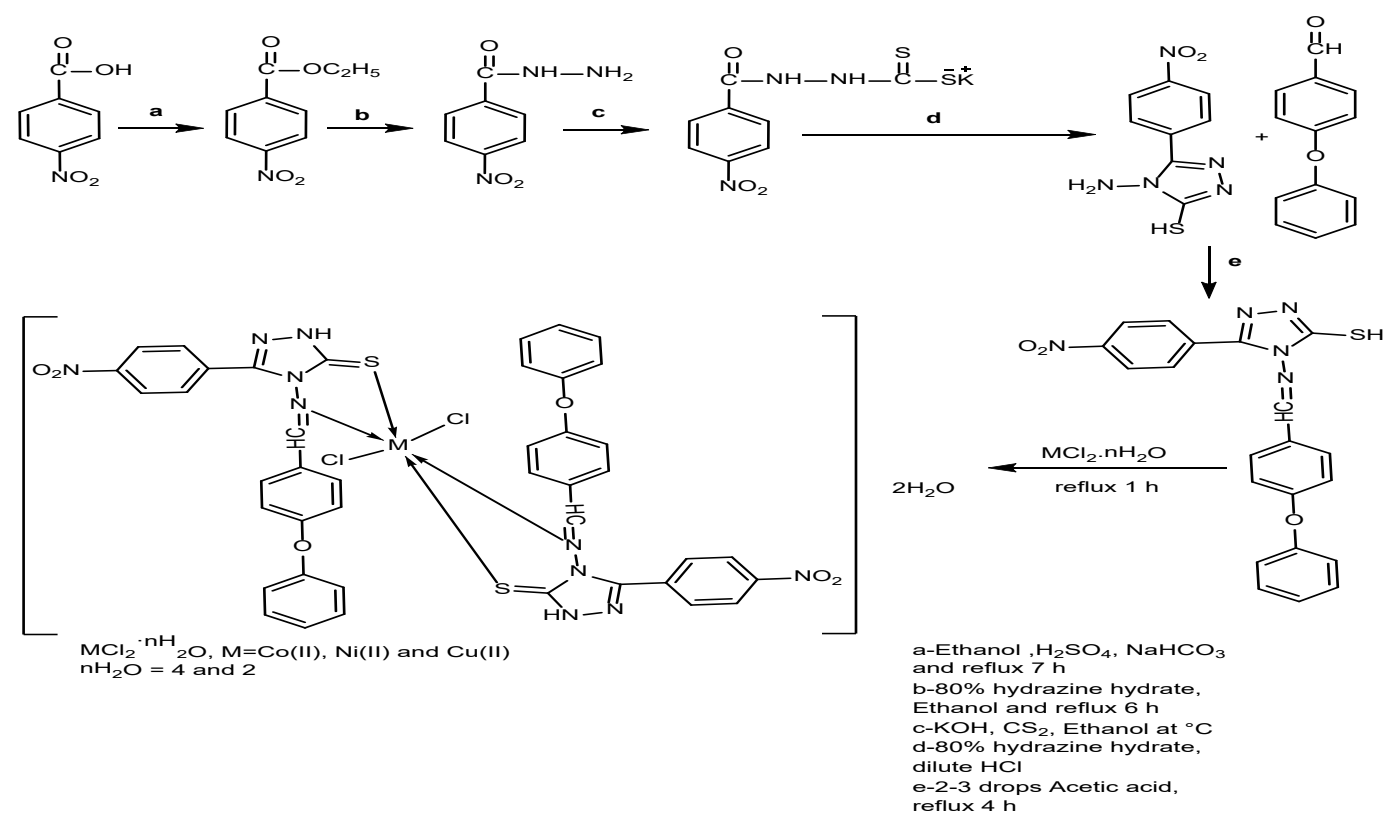

Scheme 1. Synthesis pathway of Schiff base (ligand L) and their metal complex

Table 1. Amount of metal salts in the complexes

\begin{tabular}{llll}
\hline Complex symbol & Complexes formal & Metal salts & Weight metal salts (g) \\
\hline $\mathrm{C} 1$ & {$\left[\mathrm{Co}(\mathrm{L})_{2} \mathrm{Cl}_{2}\right] \cdot 2 \mathrm{H}_{2} \mathrm{O}$} & $\mathrm{CoCl}_{2} \cdot 6 \mathrm{H}_{2} \mathrm{O}$ & 0.237 \\
$\mathrm{C} 2$ & {$\left[\mathrm{Ni}(\mathrm{L})_{2} \mathrm{Cl}_{2}\right] 2 \mathrm{H}_{2} \mathrm{O}$} & $\mathrm{NiCl}_{2} \cdot 6 \mathrm{H}_{2} \mathrm{O}$ & 0.237 \\
$\mathrm{C} 3$ & {$\left[\mathrm{Cu}(\mathrm{L})_{2} \mathrm{Cl}_{2}\right] 2 \mathrm{H}_{2} \mathrm{O}$} & $\mathrm{CuCl}_{2} \cdot 2 \mathrm{H}_{2} \mathrm{O}$ & 0.170 \\
\hline
\end{tabular}

Table 2. Physical properties and analytical data for synthesized ligand and its metal ion complexes

\begin{tabular}{|c|c|c|c|c|c|c|c|c|c|}
\hline \multirow{2}{*}{ Product } & \multirow{2}{*}{ Color } & \multirow{2}{*}{ Yield } & \multirow{2}{*}{$\begin{array}{c}\text { Molar mass } \\
(\mathrm{g} \text { mol })\end{array}$} & \multicolumn{4}{|c|}{ Micro elemental analysis found (calc.) } & \multirow{2}{*}{$\begin{array}{c}\% \text { Metal content } \\
\text { found (calc.) }\end{array}$} & \multirow{2}{*}{$\begin{array}{c}\% \text { Chloride content } \\
\text { found (calc.) }\end{array}$} \\
\hline & & & & $\% \mathrm{C}$ & $\% \mathrm{H}$ & $\% \mathrm{~N}$ & $\% \mathrm{~S}$ & & \\
\hline (L) & Yellow & 70 & 417.44 & $\begin{array}{c}59.90 \\
(60.42)\end{array}$ & $\begin{array}{c}3.44 \\
(3.62)\end{array}$ & $\begin{array}{c}3.44 \\
(3.62)\end{array}$ & $\begin{array}{c}7.20 \\
(7.68)\end{array}$ & -- & -- \\
\hline $\mathrm{C}_{1}$ & Brown & 65 & 998.73 & $\begin{array}{c}51.90 \\
(52.05)\end{array}$ & $\begin{array}{c}2.60 \\
(2.91)\end{array}$ & $\begin{array}{c}2.60 \\
(2.91)\end{array}$ & $\begin{array}{c}6.02 \\
(6.62)\end{array}$ & $\begin{array}{c}6.12 \\
(6.75)\end{array}$ & $\begin{array}{c}6.96 \\
(7.32)\end{array}$ \\
\hline $\mathrm{C}_{2}$ & Green & 70 & 988.73 & $\begin{array}{c}44.66 \\
(44.87)\end{array}$ & $\begin{array}{c}3.11 \\
(3.59)\end{array}$ & $\begin{array}{c}3.11 \\
(3.59)\end{array}$ & $\begin{array}{c}5.20 \\
(5.70)\end{array}$ & $\begin{array}{c}7.80 \\
(7.50)\end{array}$ & $\begin{array}{c}5.97 \\
(6.31)\end{array}$ \\
\hline $\mathrm{C}_{3}$ & Yellow & 70 & 1033 & $\begin{array}{c}45.01 \\
(45.68)\end{array}$ & $\begin{array}{c}2.12 \\
(2.56)\end{array}$ & $\begin{array}{c}2.12 \\
(2.56)\end{array}$ & $\begin{array}{c}5.81 \\
(5.44)\end{array}$ & $\begin{array}{c}6.12 \\
(6.33)\end{array}$ & $\begin{array}{c}6.42 \\
(7.81)\end{array}$ \\
\hline
\end{tabular}




\section{FTIR Spectrometric Analysis}

Compared to the spectrum shown in Fig. 1, the FTIR spectra of the ligand (L) showed various alterations of 4amino-5-(4-nitrophenyl)-4H-1,2,4-triazole-3-thiol. At $3160 \mathrm{~cm}^{-1}$, there was a medium intensity band associated with the $v(\mathrm{NH})$ group. The disappearance of a band at 3890 and $3400 \mathrm{~cm}^{-1}$ was due to the stretch of $v\left(\mathrm{NH}_{2}\right)$ (asymmetry and symmetry). The appearance of a new set of sharp stretching vibration bands at the frequency that is identical to the $v(\mathrm{C}=\mathrm{N})$ imine group confirmed the formation of Schiff base at $1568 \mathrm{~cm}^{-1}$, and $v(\mathrm{~S}-\mathrm{H})$ appeared as a weak band at $2550 \mathrm{~cm}^{-1}$. In all the complexes, the $(\mathrm{C}=\mathrm{N})$ imine group in the ligand $(\mathrm{L})$ was moved to a lower wavenumber, indicating that the $(\mathrm{C}=\mathrm{N})$ imine group was coordinated with the metal via the $\mathrm{N}$ atom. However, in the spectra of prepared micro complexes, the $(\mathrm{C}=\mathrm{S})$ stretching vibration shifted to higher frequencies or appeared as multiple bands with different shapes and reduced intensity. This frequency shift, change in form, and location for the stretching vibrations of the $(\mathrm{C}=\mathrm{N})$ imine and $(\mathrm{C}=\mathrm{S})$ group showed the coordination of metal ion with $(\mathrm{N})$ atom of imine group and $(\mathrm{S})$ atom of thiol group. Table 3 lists the important stretching vibrations of ligands and their complexes [11].

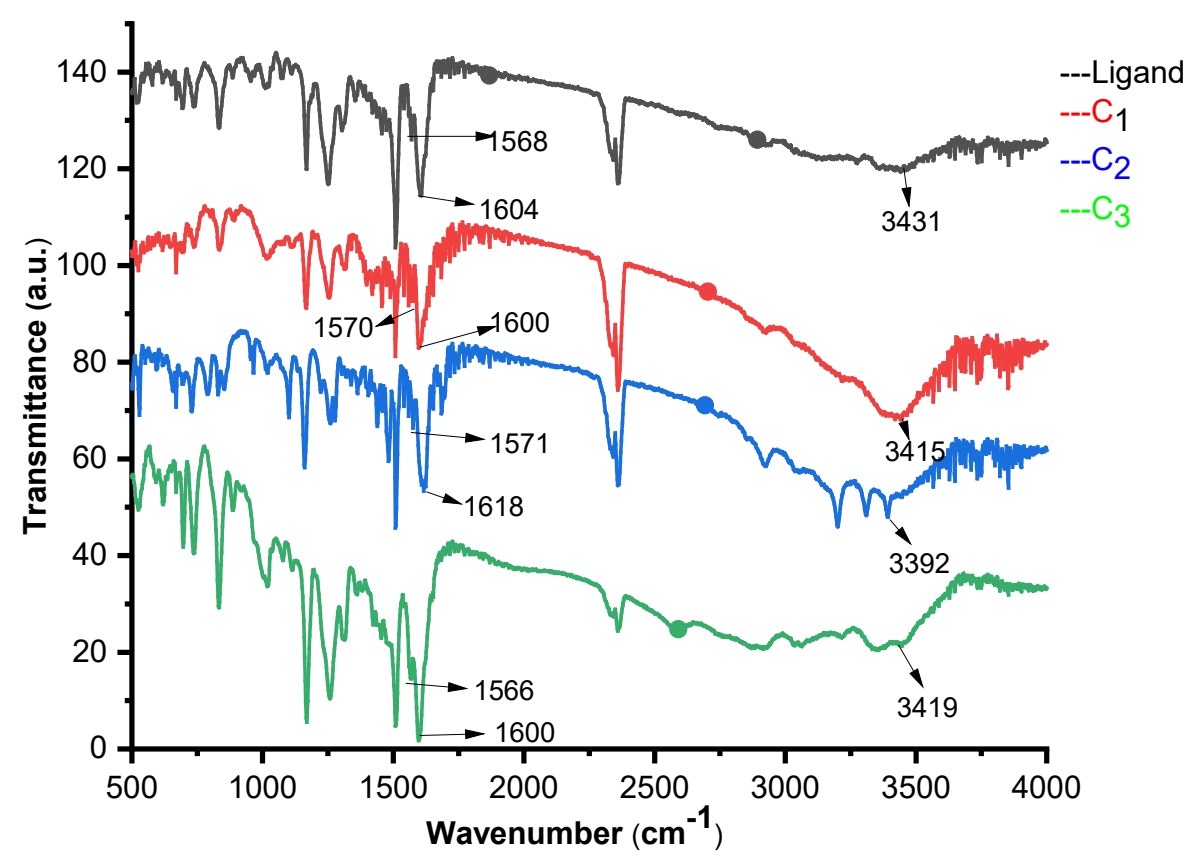

Fig 1. FTIR spectra of the Schiff base (ligand L) and its metal ion complexes $\left(C_{1}\right.$ to $\left.C_{3}\right)$

Table 3. FTIR spectral data of Schiff base (Ligand) and its complexes

\begin{tabular}{lllll}
\hline \multirow{2}{*}{ Bond } & \multicolumn{4}{c}{ Wavenumber $\left(\mathrm{cm}^{-1}\right)$} \\
& Ligand $(\mathrm{L})$ & Complex $\left(\mathrm{C}_{1}\right)$ & Complex $\left(\mathrm{C}_{2}\right)$ & Complex $\left(\mathrm{C}_{3}\right)$ \\
\hline $\mathrm{N}-\mathrm{H}$ & 3431 & 3415 & 3392 & 3419 \\
$\mathrm{C}=\mathrm{N}$ (imine) & 1568 & 1571 & 1577 & 1566 \\
$\mathrm{C}=\mathrm{N}$ (triazole) & 1604 & 1600 & 1618 & 1598 \\
$\mathrm{C}=\mathrm{S}_{\text {st }}$ & 1167 & 1167 & 1162 & 1169 \\
$\mathrm{~N}-\mathrm{O}$ & 1510 & 1510 & 1510 & 1510 \\
$\mathrm{C}-\mathrm{O}-\mathrm{C}$ & 1249 & 1253 & 1276 & 1257 \\
=C-H (aromatic) & 3033 & 3033 & 3043 & 3033 \\
$\mathrm{C}-\mathrm{H}$ (aromatic) & $694-835$ & $698-835$ & $698-831$ & $696-831$ \\
$\mathrm{C}=\mathrm{C}$ (aromatic) & 1681 & 1679 & 1689 & 1685 \\
\hline
\end{tabular}




\section{Electronic Spectra, Magnetic Susceptibility and Molar Conductance}

In a DMF solution, the UV-visible absorption spectra of ligand L are shown in Fig. 2 and summarized in Table 4. Two bands at $265 \mathrm{~nm}$ and $318 \mathrm{~nm}$ were assigned to the $\left(\pi-\pi^{\star}\right)$ transition while a band at $318 \mathrm{~nm}$ was assigned to the $\left(n-\pi^{*}\right)$ transition. In the visible region, the electronic spectra of $\mathrm{C}_{1}$ complex in DMF solvent showed two spin-allowed bands at $435 \mathrm{~nm}$ and $622 \mathrm{~nm}$, which could be associated with the transitions of the ${ }^{4} \mathrm{~T}_{1} \mathrm{~g}$ $\rightarrow{ }^{4} \mathrm{~T}_{2} \mathrm{~g}(\mathrm{f})\left(v_{2}\right)$ and ${ }^{4} \mathrm{~T}_{1} \mathrm{~g} \rightarrow{ }^{4} \mathrm{~T}_{1} \mathrm{~g}(\mathrm{p})\left(v_{3}\right)$, respectively. The $\mathrm{C}_{1}$ complex was paramagnetic, as indicated by its magnetic

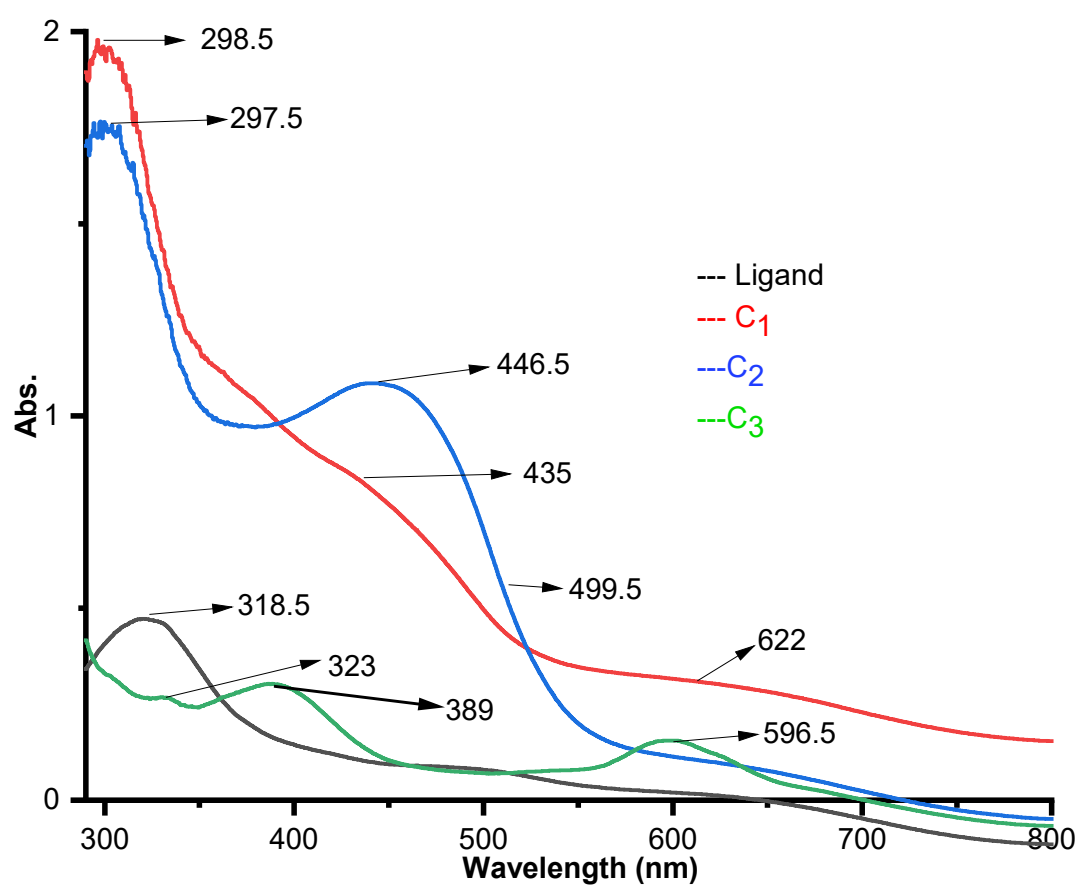

Fig 2. Electronic spectra of the ligand and its metal complexes

Table 4. Magnetic susceptibility, molar conductivity, and electronic spectral data of ligand(L)

\begin{tabular}{|c|c|c|c|c|c|}
\hline Compound & 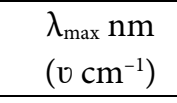 & Assignment & $\begin{array}{l}\text { Molar conductivity } \\
\mathrm{ohm}^{-1} \mathrm{~cm}^{2} \mathrm{~mol}^{-1}\end{array}$ & $\begin{array}{l}\text { Magnetic susceptibility } \\
\text { (BM) found (calc.) }\end{array}$ & $\begin{array}{l}\text { Suggested } \\
\text { geometry }\end{array}$ \\
\hline$\overline{\text { Ligand }}$ & $\begin{array}{c}265 \\
(37735.84) \\
318 \\
(31446.54)\end{array}$ & $\begin{array}{l}\left(\pi-\pi^{\star}\right) \\
\left(\mathrm{n}-\pi^{\star}\right)\end{array}$ & - & - & $\begin{array}{l}\text { Octahedral } \\
\text { geometry }\end{array}$ \\
\hline $\mathrm{C}_{1}$ & $\begin{array}{c}435 \\
(22988.50) \\
622 \\
(16077.17)\end{array}$ & $\begin{array}{l}{ }^{4} \mathrm{~T}_{1} \mathrm{~g} \rightarrow{ }^{4} \mathrm{~T}_{2} \mathrm{~g}(\mathrm{f}) \\
{ }^{4} \mathrm{~T}_{1} \mathrm{~g} \rightarrow{ }^{4} \mathrm{~T}_{1} \mathrm{~g}(\mathrm{p})\end{array}$ & 39.00 & $\begin{array}{l}3.9 \\
(3.87)\end{array}$ & $\begin{array}{l}\text { Octahedral } \\
\text { geometry }\end{array}$ \\
\hline $\mathrm{C}_{2}$ & $\begin{array}{c}499.5 \\
(20020.02) \\
446 \\
(22421.52)\end{array}$ & $\begin{array}{l}{ }^{3} \mathrm{~A}_{2} \mathrm{~g} \rightarrow{ }^{3} \mathrm{~T}_{1} \mathrm{~g}(\mathrm{f}) \\
{ }^{3} \mathrm{~A}_{2} \mathrm{~g} \rightarrow{ }^{3} \mathrm{~T}_{1} \mathrm{~g}\end{array}$ & 50.2 & $\begin{array}{r}3.10 \\
(2.8)\end{array}$ & $\begin{array}{l}\text { Octahedral } \\
\text { geometry }\end{array}$ \\
\hline $\mathrm{C}_{3}$ & $\begin{array}{c}596.5 \\
(16764.45) \\
398 \\
(25125.62)\end{array}$ & $\begin{array}{l}{ }^{2} \mathrm{~B}_{1} \mathrm{~g} \rightarrow{ }^{2} \mathrm{~B}_{2} \mathrm{~g}+{ }^{2} \mathrm{Eg} \\
{ }^{2} \mathrm{~B}_{1} \mathrm{~g} \rightarrow{ }^{2} \mathrm{~A}_{1} \mathrm{~g}\end{array}$ & 1.63 & 1.63 & $\begin{array}{l}\text { Octahedral } \\
\text { geometry }\end{array}$ \\
\hline
\end{tabular}


susceptibility of $3.9 \mathrm{BM}$, and the complex had a molar conductivity of $39.00 \mathrm{ohm}^{-1} \mathrm{~cm}^{2} \mathrm{~mol}^{-1}$ indicating that it was non-conductive as indicated in Table 4 . In addition to this information, the results of elemental (CHNS) analysis, flame atomic absorption, and FTIR spectrum supported this hypothesis, and implied an octahedral structure for the $C_{1}$ complex as shown in Fig. 3 [12]. The $\mathrm{C}_{2}$ complex's electronic spectra in DMSO solution revealed two spin-allowed bands of $499.5 \mathrm{~nm}$ and $446 \mathrm{~nm}$, which corresponded to the ${ }^{3} \mathrm{~A}_{2} \mathrm{~g} \rightarrow{ }^{3} \mathrm{~T}_{1} \mathrm{~g}$ (f) and ${ }^{3} \mathrm{~A}_{2} \mathrm{~g} \rightarrow{ }^{3} \mathrm{~T}_{1} \mathrm{~g}$ (p) transitions, respectively. Around the $\mathrm{Ni}(\mathrm{II})$ ion, these bands indicated an octahedral shape. The magnetic moment value for $\mathrm{Ni}(\mathrm{II})$ in Table 3 was $3.10 \mathrm{BM}$, which was within the range of $2.8-3.5 \mathrm{BM}$ for $\mathrm{Ni}$ (II) ion with octahedral geometry. The conductivity of this compound referred to its non-ionic performance. Thus, based on the information presented above, as well as those derived from FTIR spectra and flame atomic absorption, an octahedral geometry around the $\mathrm{Ni}$ (II) ion can be proposed as shown in Fig. 3 [13-14]. The $\mathrm{d}^{9}$ ion was characterized by a large distortion from the octahedral symmetry, and the band was asymmetrical. Several transformations have occurred, and these transitions have emerged, which cannot be easily set without ambiguity. The free ion ${ }^{2} \mathrm{D}$ term was expected to split in a crystal field in the same way as the ${ }^{5} \mathrm{D}$ term of the $\mathrm{d}^{4}$ ion, and a similar interpretation of the spectra was likewise expected. The spectrum of $\mathrm{Cu}(\mathrm{II})$ complex in the DMF solution showed one broadband at $596.5 \mathrm{~nm}$ which agreed with ${ }^{2} \mathrm{~B}_{1} \mathrm{~g} \rightarrow{ }^{2} \mathrm{~B}_{2} \mathrm{~g}+{ }^{2} \mathrm{Eg}\left(v_{2}+v_{3}\right)$ transition, and shoulder band at $398 \mathrm{~nm}$ allocated to ${ }^{2} \mathrm{~B}_{1} \mathrm{~g} \rightarrow{ }^{2} \mathrm{~A}_{1} \mathrm{~g}\left(v_{1}\right)$ transitions. The purpose of these bands was to approve extremely warped octahedral geometry with their configuration. At room temperature, the magnetic moment was $1.80 \mathrm{BM}$. The complex's conductivity in DMF revealed that it was non electrolytic. As shown in Fig. 2 the octahedral geometry around the $\mathrm{Cu}(\mathrm{II})$ ion might be inferred from the electronic spectra, FTIR spectroscopy data, and flame atomic absorption Fig. 3 [15].

\section{NMR Studies}

\section{${ }^{1} \mathrm{H}-\mathrm{NMR}$ of Schiff base (ligand L)}

Fig. 4 displays the signal assignments for the ${ }^{1} \mathrm{H}$ NMR spectrum of Schiff base (ligand L) in DMSO- $\mathrm{d}^{6}$. A key singlet $8.51 \mathrm{ppm}(1 \mathrm{H})$ was observed corresponding to the Schiff base proton [13]. The chemical shifts of aromatic and triazole ring protons were exhibited at 6.3$8.08 \mathrm{ppm}$, respectively. The spectrum showed a strong peak of thiol proton singlet at $13.10 \mathrm{ppm}(1 \mathrm{H})$ [16-17].

\section{${ }^{13}$ C-NMR of Schiff base (ligand L)}

The ${ }^{13} \mathrm{C}$-NMR spectra of the ligand is depicted in Fig. 5. The presence of the $(\mathrm{N}=\mathrm{CH})$ azomethine group in the ligand's spectra, which occurred at $158 \mathrm{ppm}$, was a distinguishing feature. Aromatic carbons shifted

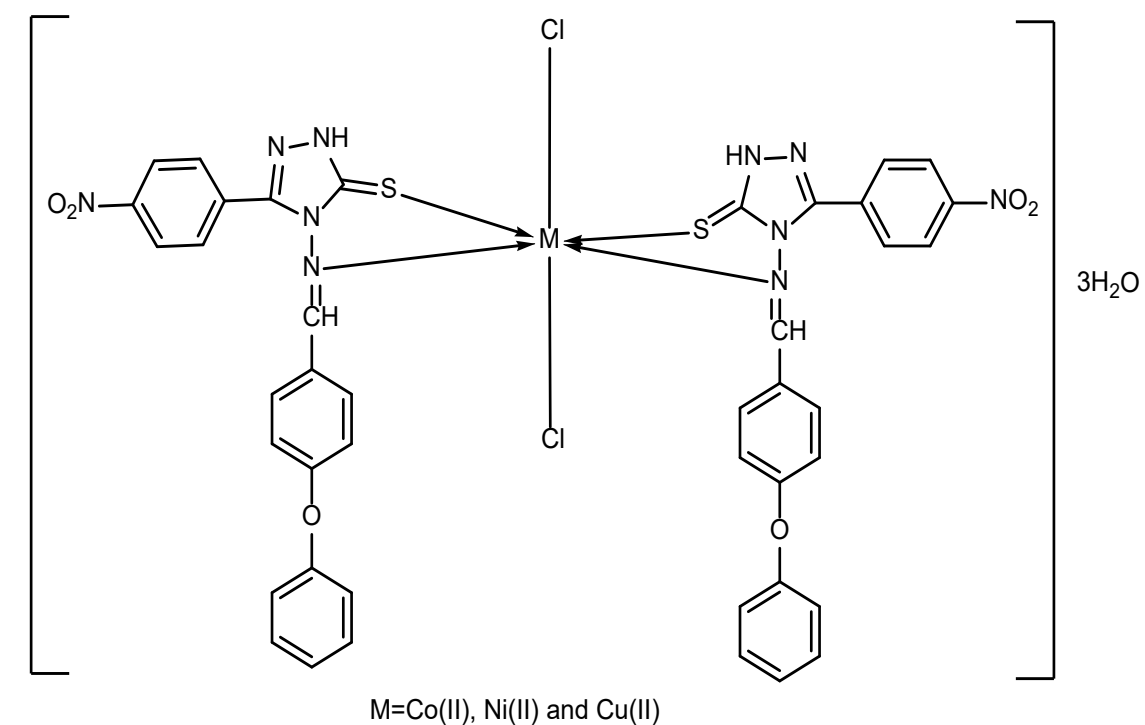

Fig 3. Suggestion of metal complexes 


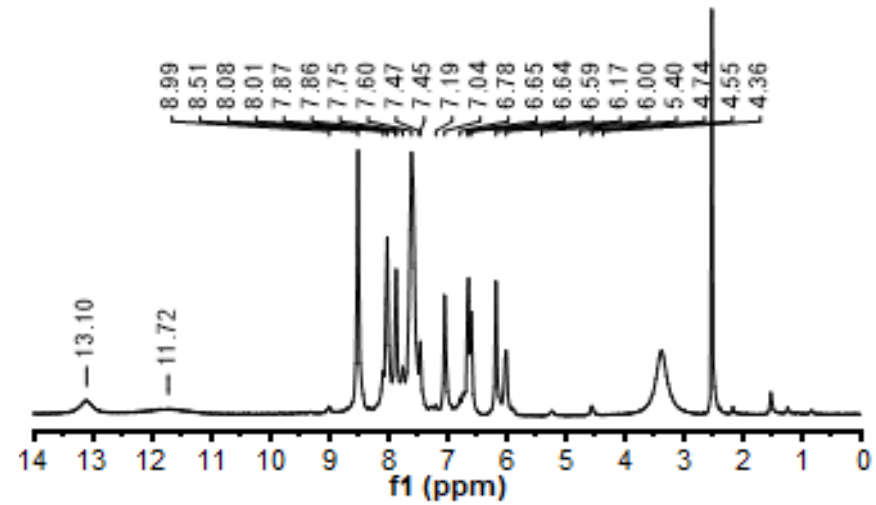

Fig 4. ${ }^{1} \mathrm{H}-\mathrm{NMR}$ spectrum of Schiff base (Ligand L)

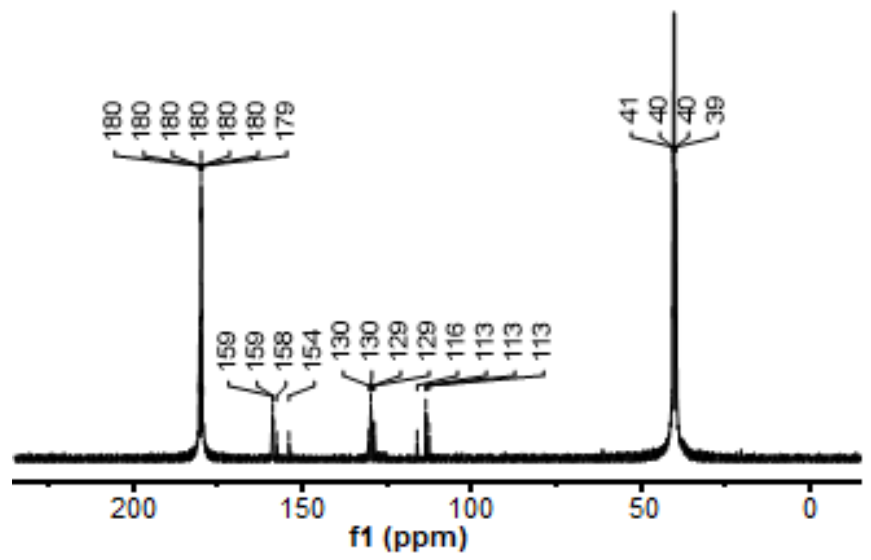

Fig 5. ${ }^{13} \mathrm{C}-\mathrm{NMR}$ Spectrum of Schiff base (Ligand L) chemically between 112 ppm and 130 ppm [17].

\section{Thermal Analysis}

\section{Thermogravimetric analysis}

Fig. 6 and 7 show indicative TG and DTG curves for the Schiff base ligand and its complexes of a metal ion [18] under the nitrogen atmosphere at a rate of $20^{\circ} \mathrm{C} / \mathrm{min}$. Table 5 shows the function of the temperature. Overall, the TG curves of the $\mathrm{C}_{1}, \mathrm{C}_{2}$, and $\mathrm{C}_{3}$ complexes displayed an early loss of weight due to evaporation of moisture, followed by a degradation step up to $200{ }^{\circ} \mathrm{C}$, and an extended degradation up to almost $900{ }^{\circ} \mathrm{C}$ for $\mathrm{C}_{1}$ and $\mathrm{C}_{2}$ complexes, and $600^{\circ} \mathrm{C}$ for $\mathrm{C}_{3}$ complex. The latter decomposition was where the majority of the weight loss occurred, with a final degradation that led to a total weight loss of over $80 \%$. Thus, after the moisture evaporation, the first degradation step of complexes was attributed to the thermal vaporization of volatile compounds. The second degradation step was most probably due to the loss of molecules from the complexes. Similarly, the Schiff base ligand (L) showed two degradation steps after dehydration [19-20]. Furthermore, the DTG curves had a small peak related to moisture loss; a steep top, which maximum temperature values were also recorded in Table 5; as well

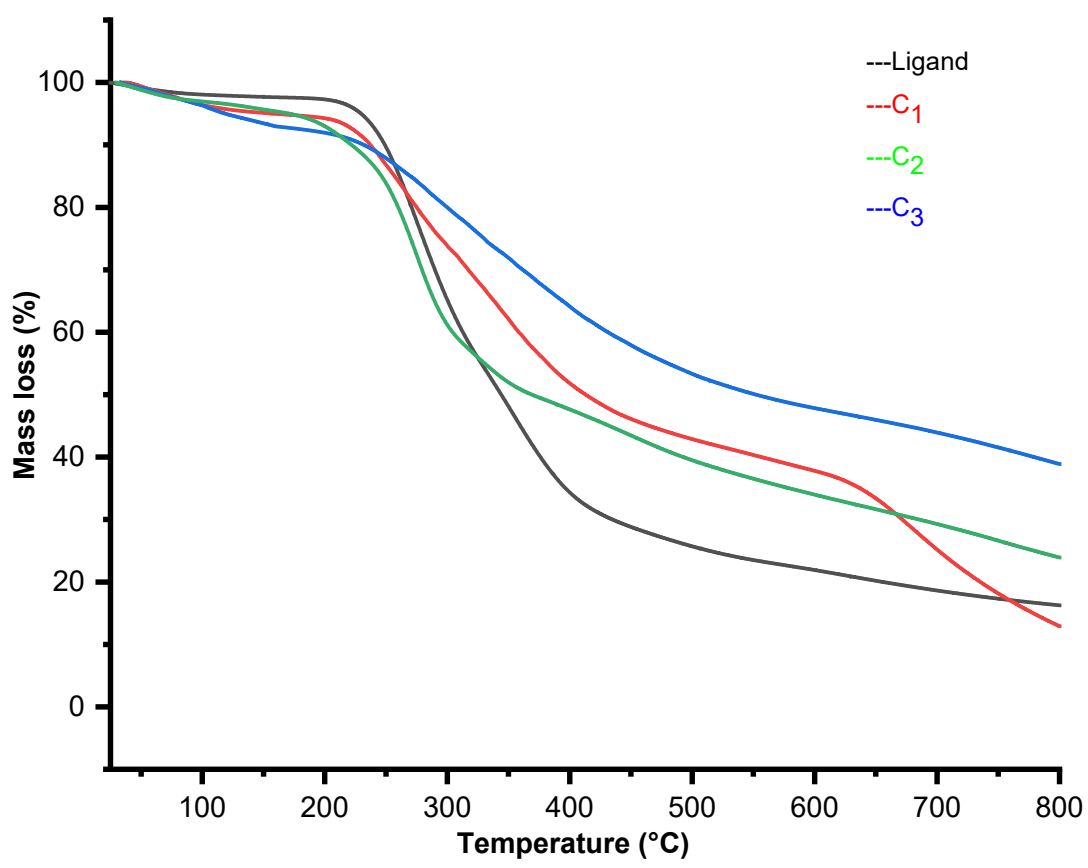

Fig 6. TG curves of the ligand and its metal ion complexes under nitrogen atmosphere at a heating rate of $20^{\circ} \mathrm{C} / \mathrm{min}$ 


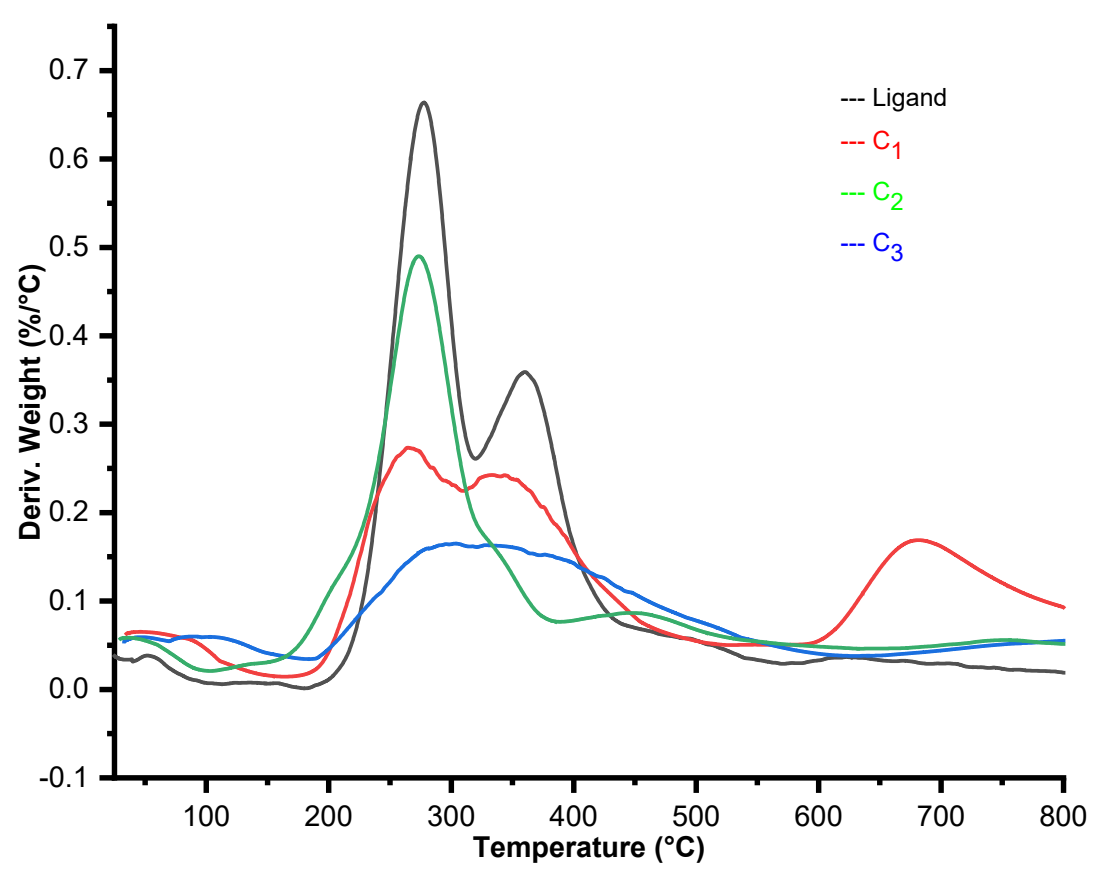

Fig 7. DTG curves of the ligand and its metal ion complexes under nitrogen atmosphere at a heating rate of $20^{\circ} \mathrm{C} / \mathrm{min}$

Table 5. Thermal decomposition data of TG/DTG curves for the ligand and its metal ion complexes under nitrogen atmosphere

\begin{tabular}{|c|c|c|c|c|c|c|}
\hline Compound & Molecular formula & $\begin{array}{c}\text { Molecular } \\
\text { weight }(\mathrm{g} / \mathrm{mol})\end{array}$ & Step & $\begin{array}{l}\text { Temperature range of } \\
\text { the decomposition }\left({ }^{\circ} \mathrm{C}\right)\end{array}$ & $\begin{array}{l}\text { Mass } \\
(\%)\end{array}$ & $\begin{array}{c}\text { DTG } \\
\text { maxima }\left({ }^{\circ} \mathrm{C}\right)\end{array}$ \\
\hline \multirow{5}{*}{ Ligand L } & \multirow{5}{*}{$\mathrm{C}_{21} \mathrm{H}_{15} \mathrm{O}_{3} \mathrm{~N}_{5} \mathrm{~S}$} & \multirow{5}{*}{417} & 1 & $0-175$ & 2.469 & \multirow{5}{*}{$\begin{array}{l}275 \\
362\end{array}$} \\
\hline & & & 2 & $175-340$ & 40.63 & \\
\hline & & & 3 & $340-560$ & 33.59 & \\
\hline & & & 4 & $560-1000$ & 12.55 & \\
\hline & & & 5 & $>1000$ & 10.761 & \\
\hline \multirow{4}{*}{$\mathrm{C}_{1}$} & \multirow{4}{*}[\mathrm{Co}(\mathrm{L})_{2}\mathrm{Cl}_{2}]{$\cdot 2 \mathrm{H}_{2} \mathrm{O}$} & \multirow{4}{*}{1072} & 1 & $0-160$ & 7.556 & \multirow{4}{*}{290} \\
\hline & & & 2 & $160-620$ & 45.08 & \\
\hline & & & 3 & $620-1000$ & 19.89 & \\
\hline & & & 4 & $>1000$ & 27.474 & \\
\hline \multirow{5}{*}{$\mathrm{C}_{2}$} & \multirow{5}{*}[\mathrm{Ni}(\mathrm{L})_{2}\mathrm{Cl}_{2}]{$\cdot 2 \mathrm{H}_{2} \mathrm{O}$} & \multirow{5}{*}{998.73} & 1 & $0-95$ & 3.071 & \multirow{5}{*}{273} \\
\hline & & & 2 & $95-390$ & 48.33 & \\
\hline & & & 3 & $390-635$ & 16.06 & \\
\hline & & & 4 & $635-1000$ & 17.32 & \\
\hline & & & 5 & $>1000$ & 15.219 & \\
\hline \multirow{5}{*}{$\mathrm{C}_{3}$} & \multirow{5}{*}[\mathrm{Cu}(\mathrm{L})_{2}\mathrm{Cl}_{2}]{$\cdot 2 \mathrm{H}_{2} \mathrm{O}$} & \multirow{5}{*}{988.73} & 1 & $0-180$ & 4.997 & \\
\hline & & & 2 & $180-360$ & 23.12 & 267 \\
\hline & & & 3 & $360-540$ & 30.68 & 339 \\
\hline & & & 4 & $540-1000$ & 38.47 & 677 \\
\hline & & & 5 & $>1000$ & 2.733 & \\
\hline
\end{tabular}

as a slight minimum owing to moisture loss, except for $\mathrm{C} 1$ that had a large and broad peak located between $600-$ $900{ }^{\circ} \mathrm{C}$. More interestingly, all of the complexes had virtually the same breakdown temperature, which was in the range of $180^{\circ} \mathrm{C}$ to $400{ }^{\circ} \mathrm{C}$, indicating that they were thermally stable. The temperature at which degradation 
began has been suggested to confirm the comparative stability of the complexes. Unlike $\mathrm{C}_{3}$ complex, $\mathrm{C}_{1}$ and $\mathrm{C}_{2}$ degradation continued at temperatures higher than $600{ }^{\circ} \mathrm{C}[20-21]$.

\section{- CONCLUSION}

Based on the process described in the literature, 2amino-triazole derivative and 4-phenoxybenzaldehyde produced the Schiff bases (ligand L). The new ligands exhibited bidentate behavior in all metal complexes, with at least one of the nitrogen of azomethine and thiol groups being used as a chelate to coordinate with copper(II), nickel(II), and cobalt(II) metal ions. The complexes were synthesized with the new ligand according to 1:2 molar ratio of the complexes and were characterized using FTIR, ${ }^{13} \mathrm{C}-\mathrm{NMR}$, and ${ }^{1} \mathrm{H}-\mathrm{NMR}$ to confirm the structures. Other analyses, such as magnetic property measurements, molar conductance, elemental analysis (CHNS), thermal analysis (TG, DTG), and atomic absorption were also performed. The results indicated that the complexes' proposed structures had an octahedral geometry. Thermogravimetric analyses of metal complexes were carried out in an inert atmosphere from room temperature to $1000^{\circ} \mathrm{C}$ at $20^{\circ} \mathrm{C} / \mathrm{min}$ of heating rate. We were able to investigate their thermal deterioration profile using TGA/DTG. Thus, the degradation of the major components occurred in two steps for $\mathrm{C}_{1}$ and $\mathrm{C}_{2}$ complexes, and one step for $\mathrm{C}_{3}$ complexes. These results could be used to predict the study biology activities behavior of these complex and could help in the evaluation of the could become a basis for further studies and at in-vitro and in-vivo levels experimental and this excellent performance would encourage us to develop more triazole derivative.

\section{- REFERENCES}

[1] Al-Khazraji, A.M.A., and Al Hassani, R.A.M., 2020, Synthesis, characterization and spectroscopic study of new metal complexes form heterocyclic compounds for photostability study, Sys Rev Pharm., 11 (5), 535-555.

[2] Sumrra, S.H., Sahrish, I., Raza, M.A., Ahmad, Z., Zafar, M.N., Chohan, Z.H., Khalid, M., and Ahmed,
S., 2020, Efficient synthesis, characterization, and in vitro bactericidal studies of unsymmetrically substituted triazole-derived Schiff base ligand and its transition metal complexes, Monatsh. Chem., 151 (4), 549-557.

[3] Bennion, J.C., McBain, A., Son, S.F., and Matzger, A.J., 2015, Design and synthesis of a series of nitrogen-rich energetic cocrystals of 5,5'-dinitro2H,2H'-3,3'-bi-1,2,4-triazole (DNBT), Cryst. Growth Des., 15 (5), 2545-2549.

[4] Peng, Z., Wang, G., Zeng, Q.H., Li, Y., Wu, Y., Liu, H., Wang, J.J., and Zhao, Y., 2021, Synthesis, antioxidant and anti-tyrosinase activity of 1,2,4triazole hydrazones as antibrowning agents, Food Chem., 341, 128265.

[5] Menteşe, E., Akyüz, G., Emirik, M., and Baltaş, N., 2019, Synthesis, in vitro urease inhibition and molecular docking studies of some novel quinazolin-4 $(3 H)$-one derivatives containing triazole, thiadiazole and thiosemicarbazide functionalities, Bioorg. Chem., 83, 289-296.

[6] Dalloul, H.M., El-nwairy, K., Shorafa, A.Z., and Samaha, A.A., 2017, Synthesis and biological activities of some new spiro 1,2,4-triazole derivatives having sulfonamide moiety, Org. Commun., 10 (4), 280-287.

[7] Jin, R., Wang, Y., Guo, H., Long, X., Li, J., Yue, S., Zhang, S., Zhang, G., Meng, Q., Wang, C., Yan, H., Tang, Y., and Zhou, S., 2020, Design, synthesis, biological activity, crystal structure and theoretical calculations of novel 1,2,4-triazole derivatives, $J$. Mol. Struct., 1202, 127234.

[8] Sahoo, P.K., Sharma, R., and Pattanayak, P., 2010, Synthesis and evaluation of 4-amino-5-phenyl- $4 \mathrm{H}$ [1,2,4]-triazole-3-thiol derivatives as antimicrobial agents, Med. Chem. Res., 19 (2), 127-135.

[9] Bader, A.T., Rasheed, N.A., Aljeboree, M., and Alkaiml, A.F., 2020, Synthesis, characterization of new 5-(4-nitrophenyl)-4-((4 phenoxybenzylidene) amino)-4H-1,2,4-triazole-3-thiol metal complexes and study of the antibacterial activity, J. Phys. Conf. Ser., 1664, 012100. 
[10] Emam, S.M., Tolan, D.A., and El-Nahas, A.M., 2020, Synthesis, structural, spectroscopic, and thermal studies of some transition-metal complexes of a ligand containing the amino mercapto triazole moiety, Appl. Organomet. Chem., 34 (5), e5591.

[11] Venugopala, K.N., Kandeel, M., Pillay, M., Deb, P.K., Abdallah, H.H., Mahomoodally, M.F., and Chopra, D., 2020, Anti-tubercular properties of 4-amino-5(4-fluoro-3-phenoxyphenyl)-4H-1,2,4-triazole-3thiol and its Schiff bases: Computational input and molecular dynamics, Antibiotics, 9 (9), 559.

[12] Rapheal, P., Manoj, E., Kurup, M.R.P., and Fun, H.K., 2021, Nickel(II) complexes of N(4)-substituted thiosemicarbazones derived from pyridine-2carbaldehyde: Crystal structures, spectral aspects and Hirshfeld surface analysis, J. Mol. Struct., 1237, 130362.

[13] Hamil, A., Khalifa, K.M., Almutaleb, A.A., and Nouradean, M.Q., 2020, Synthesis, characterization and antibacterial activity studies of some transition metal chelates of $\mathrm{Mn}(\mathrm{II}), \mathrm{Ni}(\mathrm{II})$ and $\mathrm{Cu}(\mathrm{II})$ with Schiff base derived from diacetylmonoxime with Ophenylenediamine, Adv. J. Chem. A, 3 (4), 524-533.

[14] Kargar, H., Torabi, V., Akbari, A., BehjatmaneshArdakani, R., Sahraei, A., and Tahir, M.N., 2020, $\mathrm{Pd}(\mathrm{II})$ and $\mathrm{Ni}(\mathrm{II})$ complexes containing an asymmetric Schiff base ligand: Synthesis, X-ray crystal structure, spectroscopic investigations and computational studies, J. Mol. Struct., 1205, 127642.

[15] Mahmoud, N.F., Abbas, A.A., and Mohamed, G.G., 2021, Synthesis, characterization, antimicrobial, and MOE evaluation of nano 1,2,4-triazole-based Schiff base ligand with some d-block metal ions, Appl. Organomet. Chem., 35 (6), e6219.
[16] Silverstein, R., Webster, F.X., and Kiemle, D., 2005, Spectrometric Identification of Organic Compounds, $7^{\text {th }}$ Ed., John Wiley \& Sons, Inc., Hoboken, New Jersey, USA.

[17] Amer, S., El-Wakiel, N., and El-Ghamry, H., 2013, Synthesis, spectral, antitumor and antimicrobial studies on $\mathrm{Cu}$ (II) complexes of purine and triazole Schiff base derivatives, J. Mol. Struct., 1049, 326335.

[18] Magyari, J., Holló, B.B., Rodić, M.V., Jovanović, L.S., Szécsényi, K.M., Ferenc, W., Osypiuk, D., Mosolygó, T., Kincses, A., and Spengler, G., 2020, Synthesis, characterization, thermal properties and biological activity of diazine-ring containing hydrazones and their metal complexes, J. Therm. Anal. Calorim., 2020, 1-14.

[19] Abid, M.N., Hafith, F.R., Musa, T.M., and Abbas, B.F., 2021, Synthesis, characterization and biological activity study of cobalt(II), nickel(II) and copper(II) complexes derived from mixed bidentate ligands of oxime and phenanthroline, Egypt. J. Chem., 64 (11), 6487-6492.

[20] Chaurasia, M., Tomar, D., and Chandra, S., 2019, Synthesis, spectral characterization, and DNA binding studies of $\mathrm{Co}(\mathrm{II}), \mathrm{Ni}(\mathrm{II}), \mathrm{Cu}(\mathrm{II})$ and $\mathrm{Zn}(\mathrm{II})$ complexes of Schiff base 2-((1H-1,2,4-triazol-3ylimino)methyl)-5-methoxyphenol, J. Mol. Struct., 1179, 431-442.

[21] Gaber, M., El-Ghamry, H.A., and Fathalla, S.K., 2020, Synthesis, structural identification, DNA interaction and biological studies of divalent $\mathrm{Mn}$, Co and Ni chelates of 3-amino-5-mercapto-1,2,4triazole azo ligand, Appl. Organomet. Chem., 34 (8), e5678. 